It is impossible to state at the outset just what material may or may not produce Cecidomyiidæ, since we have bred a species of Lasioptera from an apparently normal Diervilla stem only $1 / 8$ of an inch in diameter.

Afternoon Session, Friday, December 2\%, $190 \%$.

The session was called to order at $1 \mathrm{p}$. m. and the presidential address was discussed.

Mr. J. B. Smith stated that he considered the address very timely. He believed, however, that owing to the recent extension of the field of the economic entomologist that there is danger that he may unconsciously get out of his proper field of work. In insecticide investigations the entomologist should secure the coöperation of the chemist. $\mathrm{He}$ is satisfied that the diseases of the brown-tail and gypsy moths had destroyed more of the insects than the parasites, but in this field the work of the plant pathologist is needed. Certain cranberry insects have modified the entire plan of cranberry culture, while in the mosquito campaign in New Jersey, where about 15,000 acres of salt marsh have been drained by the construction of over 2,200,000 feet of ditches, the problem has become one of engineering to a large extent. $\mathrm{He}$ believed that when we get outside the range of entomology, experts in the allied sciences should be consulted.

Several other members expressed their appreciation of the address.

Mr. Newell presented the following paper:

\title{
NOTES ON THE HABITS OF THE ARGENTINE OR "NEW ORLEANS” ANT, IRIDOMYRMEX HUMILIS MAYR.
}

\section{By Wilmon Newell, Baton Rouge, La.}

It is not often that the economic entomologist is privileged to behold the coming of a new and dangerous pest, to see its numbers rapidly increasing for several years before it attracts more than casual attention from the "layman," and yet be practically powerless to avert the threatened catastrophe.

An insect problem practically unheard of by the majority of the members of this Association, is now presenting itself in the State of Louisiana, and will shortly present itself to most if not all of the southern portion of this country. It is, withal, a problem which in the writer's humble opinion will rank in magnitude alongside the problems presented by the San José scale, gypsy moth and boll weevil, but in marked contrast to these it is not likely to admit of remedial measures being as easily applied. 
In his brief experience as an entomologist, the writer has not encountered or heard of any species which exercises its destructive abilities in so many different directions. As a household pest I venture the opinion that this ant has no equal in the United States. It is both a direct and indirect enemy of horticulture; direct by actual destruction of buds, blooms and fruit, and indirect by its fostering care of various scale insects and plant lice. In the latter role it becomes also an enemy of importance to shade and ornamental trees and plants. By its association with Pseudococcus calceolariae (Mask) it may wipe out, or at least make unprofitable, the production of cane sugar in the South. By its successful antagonism of beneficial forms it becomes doubly injurious. The varieties of Solenopsis geminata, now regarded as extremely important in the natural control of the boll weevil, are likely to be greatly reduced in numbers by Iridomyrmex humilis and thus the latter species may become the indirect cause of damage to the cotton crop. Even as a menace to human life, under certain circumstances, this little ant cannot be entirely ignored. To this I shall refer later.

\section{History and Introduction.}

The species was first described as "Hypoclinea humilis" by G. Mayr, in 1868, from workers collected in 1866 near Buenos Ayres in Argentina, the original description appearing in the Annuario della Soc. Naturatisti Modena, Vol. III, page 164. Following is Mayr's description of the species, kindly furnished by Dr. W. M. Wheeler of the American Museum of Natural History, from the original edition:

"Operia: Long, $2.6 \mathrm{~mm}$. Sordide ferruginea, micans, mandibularum parte apicali flavescenti, abdomine nigrofusco, tarsis et nonnunquam tibiis testaceis ; miscroscopice adpresse pubescens; absque pilis abstantibus; subtilissime coriaceo-rugulosa, mandibulis nitidis sublaevigatis punctis nonnullis; clypeus margine antico late haud profunde emarginatus; thorax inter mesonotom et metanotum paulo et distincte constrictus, pronoto fornicato, mesonoto longitrorsum recto, transversim convexo, metanoto inermi longitrorsum fornicato, pronoto paulo altiori ; petioli squama compressa rotundata."

No mention of this species in the literature on economic entomology seems to have appeared prior to the publication of a paper by E. S. G. Titus, of the Bureau of Entomology, in the proceedings of the Seventeenth Annual Meeting of this Association, ${ }^{a}$ reciting his observations made upon a trip to New Orleans in July, 1904, at the request of Prof. H. A. Morgan, who prior to that time, had recognized the dangerous nature of the pest. Mr. Titus's paper is replete with inter-

aBulletin No. 52, Bureau of Entomology, U. S. Dept. Agr., p. 78-84. 
esting information and in fact he secured a surprising amount of data in the limited time at his disposal. Since 1904 the species has frequently been referred to in the Louisiana press, usually as "the ant."

As with most imported species, the original time and place at which a foothold was obtained by the Argentine ant in Louisiana, must be largely conjectured. However, we are able to conjecture with rather strong circumstantial evidence to guide us. Not only does the testimony of inhabitants indicate New Orleans to be the original starting point of this species in the South, but its enormous numbers and the extent to which it has exterminated other species of Formicina confirm the opinion that it has been in New Orleans longer than elsewhere.

For the earliest record of its occurrence in New Orleans, I am indebted to Mr. Ed. Foster of the editorial staff of the New Orleans Daily Picayune. Mr. Foster has for years been a close student of insect life, and especially of Hymenoptera, so that his testimony may be accepted with the same confidence as that of a professional entomologist. Mr. Foster first noted humilis in New Orleans in 1891 and in a personal letter to the writer he thus gives the record:

"I have known the species since 1891. At that time it was a rarity in Audubon Park, but was very common in the section immediately above Canal Street. Below Canal Street it was not at all plentiful. The boundary of the nuisance then was virtually from Magazine Street to the river. The coffee ships from Brazil, I understand, have always landed about where the wharves are now situated (on the river front, adjoining the area above-mentioned), but from what we know of the spread of insect nuisances, the first batch of immigrants must have come in years before I came across their descendants."

Mr. Titus, quoting Mr. Baker, former Superintendent of Audubon Park, states that in 1896 "they extended over but a small area, reaching approximately from Southport docks to Carrollton Avenue, and from the river back to Poplar Street," and that "in 1899 they were first noticed in Audubon Park." This area, from Southport to Carrollton Avenue, is located about five or six miles northwest of the area between Magazine Street and the river, noted by Foster to be well infested as early as 1891. Mr. Baker therefore had not been familiar with the original area of heavy infestation, but merely noted the species after it had invaded the part of the town where he resided. Mr. Titus's information regarding the species being first noted in Audubon Park in 1899 was of course secured from citizens, who failed to note the ant until it had reached prodigious numbers in the same place that Foster had found it a "rarity" in 1891. The dissemination to Audubon Park was undoubtedly from the heavily infested area between Magazine Street and the wharves already referred to. 
For years coffee ships from Brazilian ports have unloaded their cargoes at these wharves, and from what we now know of the habits of this ant, a ship could hardly set sail from any port where it occurs without carrying many workers and doubtless many queens as well.

On the authority of Prof. W. M. Wheeler ${ }^{\mathrm{b}}, I$. humilis is apparently a native of the Americas only in Brazil and Argentina. That the species was brought to New Orleans in the coffee ships from Brazil, seems so highly probable as to admit of little doubt. Incidentally it may be remarked that few, if any, merchant vessels now clear from the port of New Orleans during the summer months without having an abundant supply of humilis on board.

It may not be out of place at this point to call attention to the common name of this insect. The local name of "crazy ant" has been applied to this species by some of the inhabitants of New Orleans, but it is far from being a desirable name. The most universal name in use is that of "New Orleans ant" and this seems to have been adopted by common consent on account of the species being so abundant in New Orleans. In view of the probable future importance of this insect the common name adopted now will likely remain a fixture in popular entomological literature.

It is manifestly unjust to attach the name of the Crescent City to this pernicious pest, for on neither the city nor its inhabitants can the responsibility be saddled for the introduction of this little ant.

As the species was first described from Argentina and as that country doubtless embraces a large part of the area in which the species is native, I should like to propose the name "Argentine ant" as being far more appropriate and specific than any yet suggested. I should like to see the species so recognized in the official list of insect names adopted and revised from time to time by this Association.

The dissemination of the Argentine ant from New Orleans to towns along the principal railroad lines within 200 miles of the city has not been particularly rapid, but has been very complete. To the eastward of New Orleans the infestation extends into southern Mississippi and to the westward as far as Lake Charles, La., a distance of two hundred miles, or nearly to the Louisiana-Texas state line. Down the Mississippi River the infestation is heavy the entire distance to the Gulf of Mexico, a distance of ninety miles. Northward the infestation reaches again into the State of Mississippi and in a more northwesterly

bEntomological News, Jan., 1906, p. 24.

cSince the above was written, Prof. W. M. Wheeler has advised the writer that the term "crazy ant" is applied in Florida and the West Indies to another species, Prenolepis longicornis. 
direction at least as far as Alexandria, La., a distance of one hundred and ninety miles from New Orleans. Fully five thousand square miles are now included in the infested territory. Artificial dissemination is by far the most important means of distribution. Mr. Titus in his paper reviewed very completely this phase of the subject. Suffice to say that individuals by thousands, and even complete colonies, travel from infested points in shipments of groceries, feed stuffs, manufactured articles, timbers, etc. The spread of the species from the railroad towns into the surrounding country and into the broad iields of the large plantations is comparatively slow and in only a small part of the area designated as infested is the ant universally distributed through both town and country.

\section{Economic Importance.}

It is as a household pest that this ant has thus far attracted the most attention. Under houses, in dooryards, beneath outhouses, in compost heaps, in hollow trees and between the walls of dwellings the nests or colonies occur in abundance. From these nests foragers go forth by day and by night, being deterred only when the temperature falls below about $50^{\circ} \mathrm{F}$. Whenever a foraging worker discovers anything which will serve as food hundreds and thousands of workers will gather within the half hour. In the case of my own residence, a new building, every square inch of surface in each room is regularly "patrolled" by the individual "scouts." No trunk, closet, book case, nor corner is left unexplored, and this despite the fact that since last spring I have waged constant warfare against them by destroying dozens of colonies with bisulphide of carbon.

Among the substances which serve the species as food may be mentioned sugars and syrups of all kinds, fresh meat, blood, lard, cream, fruit juices, honey, cakes and dead insects. Very few repellants are successful in protecting food stuffs. Even the time-honored method of placing table legs in bowls of water is but partially effective, for with the first accumulation of a dust film on the water the workers cross it without difficulty. In fact the surface film of perfectly fresh water is almost strong enough to support workers, and on more than one occasion I have seen a worker alternately swimming and walking across the surface of the water. Grocers, restaurant keepers and wholesale houses lose heavily by the inroads of this pest. A jug of molasses or a barrel of sugar, for example, containing several thousand ants is not entirely acceptable to the customer. The species does not sting, but can bite severely when so inclined, and sometimes becomes an annoyance to human beings. I have known of several cases where 
people have had to place their beds, during the summer months, upon panes of glass covered with vaseline in order to pass the night in peace. There have been rumored cases of infants being killed by these ants, but so extreme a case has not come within my observation. That such might easily occur is not at all improbable. A neighbor of mine was awakened one night the past summer by the cries of an infant, about two months of age, lying in its cradle near at hand. Thousands of these ants were crawling over the child's body and into mouth and nostrils. It was necessary to repeatedly submerge the infant in a tub of water before all the persistent workers could be disposed of. Had the child not received immediate attention the consequences would doubtless have been serious.

The Argentine ant is particularly fond of the honey-dew secreted by Aphids and various scale insects, and in all localities the increase of Coccidae and Aphididae following the increase of these ants has been almost beyond belief. Many thousands of ornamental trees and plants in New Orleans have already been destroyed by scale-insects. Many complaints are also received that the workers eat into the petals and calyces of flowers of various kinds, and indeed it has now become almost impossible to produce cut flowers with profit in the city of New Orleans.

During the past autumn I have noticed the workers of this species assiduously attending the ordinary cotton plant-lice, apparently colonizing them upon the younger foliage. The cotton-louse is a species which is usually brought fully under control by natural enemies after the middle of June, but should this ant succeed in facilitating their increase during the summer and autumn these Aphids may come prominently to the front as enemies of the cotton crop.

As a direct enemy to fruit the ant is also important. At Audubon Park the past spring the entire prospective orange crop was destroyed by them, the workers eating into the opening fruit buds. Many complaints of this injury to oranges were reported to us from the lower Mississippi River and coast regions. The fig crop in the vicinity of New Orleans was this year almost entirely destroyed by them. The following, quoted from the New Orleans Times-Democrat of July 7, 1907, is not overdrawn: "The time of the ripening of the figs has come and the housekeepers have to watch the rich harvest of figs falling to earth day after day in their green immaturity from the beautiful trees that are so ant-infested it is almost impossible to pick the few that do ripen. The trees themselves are making a noble fight, but they will be conquered in the end, because the hordes that attack them are illimitable and possess a high intelligence simply marvelous when with our feeble human efforts we try to over-reach them." 
It is in its relationship to the eane growing industry that I. humilis: promises to be of most importance. Wherever this ant has become exceedingly abundant in the cane fields a mealy-bug locally known as the "poo-a-pouche" increases with great rapidity. This latter insect has been identified by Mr. J. G. Sanders of the Bureau of Entomology as Pseudococcus calceolariae (Mask). Not only does the poo-a-pouche heavily infest the growing cane, finding lodgment between the leaf and the cane itself and drawing heavily upon the sap, but in the spring of the year it is apparently colonized upon cane underground by Iridomyrmex humilis, and there it proceeds to destroy the germinating buds of the "plant cane." By way of parenthesis I should perhaps explain that one of the methods of propagating sugar cane is to plant the previous year's canes in rows during the winter and the bud at each joint develops the following spring, sending up a rapidly growing shoot. By the destruction of these developing buds below the surface of the ground in spring, the prospective cane crop is as completely destroyed as would be a crop of corn were some insect to devour all of the seed planted.

Mr. J. B. Garrett, of the Louisiana Experiment Stations, who has recently been making a study of this poo-a-pouche, finds that its distribution is by no means co-extensive with that of the ant, and that it occurs only in a small part of the territory now occupied by the latter. The poo-a-pouche occurs in destructive numbers on the plantations from New Orleans to the mouth of the Mississippi River, a distance of ninety miles. The fact remains, however, that this is the territory in which the ant is most numerous and most firmly established.

Mr. Garrett also expresses doubt as to the ant actually colonizing the poo-a-pouche upon the cane, and suggests at the same time that the unusual increase of the poo-a-pouche may be due to protection from its natural enemies, afforded by the ants. It happens that the varieties of cane most susceptible to this injury are among the best ones at present grown in the South. Unless some unforeseen factor injects itself into this problem, the entire sugar industry of the South will be threatened by this poo-a-pouche and the attending Argentine ant, which seems to be responsible for its rapid increase.

An interesting food habit of this species has become apparent to truck growers. The workers are very fond of lettuce seed and while we are not as yet certain that the lettuce seed are harvested from the mature plants, it is well established that the workers industriously dig up and carry to their nests freshly planted seed from the gardener's beds. In the infested territory some expedient has to be resorted to to protect the lettuce seed until they germinate, by which time they are safe from the attacks of this ant. The workers are fond 
of corn meal, and if this be strewed thickly on top of the rows containing the lettuce seed, the ants will undertake to carry it away. By the time the meal is all removed, the lettuce seed has usually germinated. This practice is the most common one among the truck-growers. I have succeeded in protecting the lettuce seed by using tobacco dust scattered liberally on the ground over the seed, but it is not an entirely efficient repellent, for a small percentage of the workers burrow through it, seemingly without inconvenience or annoyance.

In what other fields this ant of cosmopolitan habits will become a disturbing factor remains to be seen.

\section{Description.}

In all the colonies which we have had under observation for several months, not more than three forms have been found, the females or queens, workers and males. Major and minor workers do not seem to occur nor do any individuals more than others act as soldiers or scouts. The original description of the worker by Mayr has been quoted above. As far as the writer can learn, the queen and male as well as the immature forms, have not heretofore been described.

At my request Prof. W. M. Wheeler has prepared a re-description of the worker, and descriptions of the queen and male, thus making a complete and comprehensive description of the species, which I give herewith :

Iridomyrmex humilis Mayr.

"Hypoclinea humilis Mayr. Annu. Soc. Natural Modena, 1868, 3: 144, No. 4, worker.

"Hypoclinea (Iridomyrmex) humilis Mayr, Verh. Zool. botan. Ges. Wien, 1870, $20: 954,958$, worker.

"Iridomyrmex humilis Emery, Zeitschr. f. wiss. zool. 46, 1888, p. 386 . Taf. 28, Figs. 17-19 (gizzard).

Worker: Length $2.2-2.6 \mathrm{~mm}$.

"Head oval, broader behind than in front, with its posterior margin slightly concave in the middle. Eyes flattened, in front of the middle of the head. Mandibles with two larger apical and several minute basal teeth. Clypeus short, convex in the middle, with broadly excised anterior margin. Frontal area and groove present but rather indistinct. Antennal scapes extending about one fourth their length beyond the posterior corners of the head. Joints 1-5 and the terminal joint of the funiculus distinctly longer than broad; remaining joints nearly as broad as long. Thorax slender, narrower than the head; broadest through the pronotum which is convex, rounded and nearly as long as broad. Mesonotum nearly as long as the pronotum, sloping, laterally compressed, in profile evenly continuing the contour of the pronotum. Mesoëpinotal constriction rather deep, extending obliquely downward and backward on each side. Epinotum short, nearly twice as high as long, convex on the sides, with a short convex base, and a longer, flatter and more sloping declivity. Petiole small, less than half as broad as the epino- 
tum; its scale in profile, compressed, cuneate, inclined forward, with flattened anterior and posterior surfaces and rather acute apex; seen from behind its border is entire and evenly rounded or even slightly produced upward in the middle. Gaster small. Legs rather slender.

"Body minutely shagreened or coriaceous, subopaque and glossy ; mandibles, clypeus and anterior border of the head more shining. Mandibles minutely and rather obscurely punctate.

"Hairs few, suberect, yellowish, confined to the mandibles, clypeus, tip and lower surface of the gaster. Pubescence short and uniform, grayish, so that the body has a slightly pruinose appearance.

"Brown; Thorax, scapes and legs somewhat paler; mandibles yellowish; apices of the individual funicular joints blackish.

Female (deälated) : Length $4.5-5 \mathrm{~mm}$.

"Head without the mandibles, but little longer than broad, with rather angular posterior corners, straight, subparallel sides and straight posterior border. Eyes large and rather convex. Mandibles and clypeus like that of the worker, scapes proportionally shorter and stouter. Thorax large, as broad as the head, elongate elliptical, nearly three times as long as broad. In profile the scutellum is very convex, projecting above the meso- and epinotum. Epinotum with very short base and long abrupt declivity. Petiolar node erect, more than half as broad as the epinotum. Gaster elliptical, somewhat shorter and a little broader than the thorax. Legs slender.

"Sculpture like that of the worker but more opaque; mandibles and clypeus also less shining.

"Scattered hairs more numerous than in the worker and also present in small numbers on the vertex, gula, mesonotum, prosternum and fore coxae. There is also a row of short hairs along the posterior margin of each gastric segment. Pubescence distinctly longer, more silky, and denser than in the worker.

"Dark brown; antennae, legs and posterior margins of the gastric segments reddish ; mandibles, sutures of thorax and articulations of legs yellow.

Male: Length $2.8-3 \mathrm{~mm}$.

"Head much flattened; including the flattened eyes, as broad as long. Vertex and ocelli prominent. Cheeks short. Mandibles small, overlapping, with a single, acuminate apical tooth. Anterior clypeal border straight. Antennae slender; scape only between three and four times as long as broad; first funicular joint globose, broader than any of the other joints; second joint much longer than the scape; joints $3-5$ growing successively shorter; joints 6-12 considerably shorter and more slender. Thorax very robust, elliptical, broader than the head, which is over-arched by the protruding, rounded mesonotum. Scutellum even more prominent than in the female. Epinotum with subequal base and declivity, the former slightly convex, the latter feebly concave, forming an angle with each other. Petiole small, its node with rather blunt margin, slightly inclined forward. Gaster very small, elongate eliptical, with small rounded external genital valves. Legs slender. Wings with a four-sided discal cell and two well developed cubital cells. The costal margin is depressed or folded in just proximally to the stigma.

"Sculpture, pilosity and pubescence as in the worker; coolr more like that of the female, except that the antennae, legs, mandibles and internal genitalia are pale, sordid yellow. Wings smoky hyaline, with brown veins and stigma. 
"I. humilis belongs to a small group of neotropical species embracing also I. iniquus Mayr, dispertitus Forel, keiteli Forel and melleus Wheeler. The workers of keiteli and melleus may be at once distinguished by their color, the former having a yellowish brown head and thorax and the remaining parts brownish yellow; the latter being pale yellow with a blackish gaster and funiculus. In these and in I. iniquus and dispertitus the mesoëpinotal constriction is much deeper than in humilis and the meso- and epinotum are of a different shape. The mesonotum in profile does not form a continuous, even line with the pronotum and the epinotum is very protuberant and almost conical. I. humilis represents a transition from the above group of species to that of $I$. analis Ern. André, which is very common in the Southern States. This species has a shorter, more robust thorax, more like that of Tapinoma, and much less constricted in the mesoëpinotal region.

"The above description was drawn from a number of workers, males and females taken from the same nest in Baton Rouge, La., by Mr. Wilmon Newell. The types described by Mayr were captured by Prof. P. de Strobel in the environs of Buenos Ayres."

An interesting point concerning the males, is that in certain colonies they occur in great abundance. This was first discovered by one of my assistants, Mr. G. A. Runner, who in December of 1907 found a colony in which the winged males were almost as abundant as the workers. Many other colonies which have been under constant observation for the past five months have not contained males at any time during that period. Prof. Wheeler has suggested that doubtless the appearance of a great many males in certain colonies is accounted for by the presence of egg-laying workers therein.

The Egg.-The egg deposited by the queen is elliptical, pearly white and without markings. As the time approaches for it to hatch it becomes duller in appearance but does not perceptibly change color.

The average size of the egg is $.3 \mathrm{~mm}$. long by $.2 \mathrm{~mm}$. wide.

The largest egg encountered while measuring a series was $.34 \mathrm{~mm}$. long by $.24 \mathrm{~mm}$. wide, and the smallest $.27 \mathrm{~mm}$. by $.187 \mathrm{~mm}$.

The rate of egg deposition has not been determined, but one queen under observation in a cage deposited at the rate of 30 eggs per day, now and then suspending oviposition for several days at a time.

The incubation period of the eggs in a glass cage in the laboratory extended from Oct. 1st to Nov. 15th, a period of 45 days, during which time the maximum temperature was $87^{\circ}$ and the minimum $29^{\circ}$, with an average daily mean of $63^{\circ}$. Calculating the effective temperature from $43^{\circ} \mathrm{F}$. and the actual mean for each day we find that 941 degrees of effective temperature were required for the develop- 
ment of these eggs. This figure seems unreasonably high and I think it accounted for by the fact that I failed to provide the nest with sufficient moisture to make the conditions for incubation entirely favorable.

The Larva.-The larva when first hatched is hardly larger than the egg, and for some time after hatching remains curved, with the head and anal end practically together, so that the very young larva and eggs cannot be distinguished from each other without the aid of a good glass.

The larva is pure white, but with a dark color sometimes appearing in the abdominal region, as if it had been fed with some black or darkcolored food. When fully grown the larvae average $1.7 \mathrm{~mm}$. long by $.66 \mathrm{~mm}$. wide.

Larvæ which were hatched from the eggs on Nov. 15, 1907, and which have been kept in a nest in my office, at ordinary living room temperature, now (Jan. 2, 1908) look to be fully grown and ready to pupate.

The Pupa.-The pupa in its earlier stage is pure white, without markings, except the compound eyes, which are jet-black and very prominent. As time for transformation approaches the pupa assumes a light brownish color, which gradually becomes a medium brown. So far as I can see there is no cocoon, or anything resembling it, surrounding the pupa, although the pupal skin, very thin and very fragile, is shed when the transformation to imago takes place. These pupal skins are carried out of the nest by the attendant workers. The color of the pupa in its final stage and that of the worker just transformed are practically identical, the latter requiring from two to five days after transformation to attain the deep brown color of the fully matured worker.

I have not secured any direct data upon the duration of the pupal stage, but from general observations my impression is that about three weeks' time, at an average temperature of $72^{\circ} \mathrm{F}$. are required.

Habits.- Reference has already been made to the feeding habits of this ant, as well as to its relations with certain Coceidæ and Aphididæ. The colonies or nests are established in a great variety of places. We have found them in swampy ground where the earth was so wet that water would drip from it when squeezed in the hand. On the other hand I have found their nests between the walls of dwellings, where no moisture could reach them except such as was contained in the air. Nests have been found within hollow trees, beneath the rough bark of growing trees, in forks of trees, in rubbish and compost heaps, in decaying timbers, beneath boxes and boards, inside of brick foundations where accidental crevices occurred, in stored household goods, 
and one colony was found domiciled between the tin wall and veneer covering of an abandoned kerosene can. In short, any locality that offers protection from the elements becomes a satisfactory home for this little creature. The species shows a marked tendency to construct nests in close proximity to any abundant food supply. If honey or molasses be placed in the same spot upon the ground for several days in succession, a small colony invariably burrows into the earth beside it. As to how new colonies are established, I am still very much in doubt. I have examined a considerable number of small nests which I knew to be but recently occupied, finding in them workers, eggs and larvæ but no queen. On the other hand I have found queens with foraging workers; one such was found with several hundred workers in a sack of sugar which was thoughtlessly left exposed for a few hours, and in rare instances a queen is seen crawling about unattended by any workers at all.

One of my assistants, Mr. G. D. Smith, has suggested that the communistic habit is carried by this species even beyond the colony itself and that colonies adjacent to each other form "communities," the inhabitants of which recognize each other as friends. There is indeed evidence to support this view. For example three colonies located in a line, about fifteen feet apart, were found to be in touch with each other, workers constantly traveling from one to the other.

The number of queens present in a colony may vary from one to many. I took as many as thirty-two queens from one colony and there were several more in sight when my supply of empty pill boxes became exhausted. It may be that the multiplicity of queens, and the age to which the workers attain, rather than the rate of oviposition, may account for the great abundance of individuals. The same theory might also explain why so many years have been required to bring the species into prominence after its introduction, as well as explaining its present strength. The increase of this pest strikes one as being steady and powerful, rather than sudden.

Though valiant fighters when other ants are encountered, the Argentine ant cannot be classed as a predaceous insect. I have yet to find them attacking any living insect or animal, the one exception being a cockroach which had been mashed, but which still possessed enough life to now and then move a leg or antenna. After insects are killed the ants feed greedily upon the body juices. They and my honey bees feed peacefully from the same dish of honey, and I have seen the ants clean off a bee which had been daubed with honey, without apparent annoyance to the latter.

Relation to Other Ants.-Prof. M. W. Wheeler, in Entomological News for January, 1906, gives an interesting account of how this 
species obtained a foothold in Madeira and supplanted another introduced species, Pheidole megacephala Fabr.

In New Orleans where I. humilis is thoroughly established everywhere, it is rare indeed to find any other species. Titus in recounting his observations in 1904 said, "they have driven or killed out all other ants in the regions infested by them." The extermination of other species in the city of New Orleans has not been complete, but very nearly so. At Baton Rouge and other points which are now becoming quite heavily infested, the displacement of the native ants is easily observed. As examples I may cite two or three cases which have come under my observation. One day in August I noticed a small colony of $I$. humilis constructing a nest but a few inches distant from a colony of their near relatives, Iridomyrmex analis. ${ }^{\mathrm{d}}$ It was not long until the foraging workers from the humilis colony discovered their neighbors and whenever workers from the two colonies met a fierce battle ensued, usually ending in the analis worker being severely bitten and left to die. Five hours after these preliminary "skirmishes"' were noticed I returned to the nest, to find humilis fully in possession and none of the former occupants of the nest anywhere in sight. The nest was dug up, but no trace of analis was found in it.

In September I witnessed an interesting attack by the humilis workers upon a fairly strong colony of Solenopsis geminata. The latter species is famed for its vindictiveness and for the effectiveness with which it uses its sting. In this case the victory was by no means an easy one for the Argentine ants, for the small (minor) workers of geminata were, one with another, as good fighters as the former. Both species made the petiole of the abdomen the objective point of attack, gripping it firmly between the jaws. About as many of the humilis workers were killed in these encounters as of the other species.

In attacking the larger (major) workers of geminata the humilis workers adopted somewhat different tacties. The geminata majors were several times larger than their antagonists and while far less active, quickly destroyed any humilis so unfortunate as to get between their mandibles. The Argentine ants therefore attacked them by rushing up and biting a leg or antenna and immediately retreating, sometimes as many as ten of the Argentines being thus engaged in the attack upon one of these major workers. Eventually the battle was won by $I$. humilis, purely by having innumerable reinforcements, and in about twenty hours had possession of the fortress they had stormed so long and faithfully.

The next morning in looking over the battleground I found many of the geminata major workers still alive but divested of all their legs.

dDetermined by Dr. W. E. Hinds. 
More interesting still was an attack made by Argentine workers upon the giant Camponotus herculeanus L., subspecies pennsylvanicus De G. ${ }^{e} \quad$ While watching a heavy stream of $I$. humilis workers passing up and down the bark of a large water oak tree one afternoon, three or four workers of the former species made their appearance, seeking food here and there on the same tree. Presently one of these giants crossed the line of humilis workers and was immediately attacked, the small ants fastening themselves to tibiæ, tarsi and antennæ and hanging on with bull-dog tenacity. With marvelous rapidity the large worker eaught from one to three of her small adversaries at a time, crushed them between her jaws and threw them aside. She would reach from side to side and twist about to crush the little enemies clinging to her tarsi, but as fast as she could dispose of them others took their places. The extreme hatred which the little workers displayed towards this giant that had crossed their path was indicated by an Argentine worker which crossed the bark a couple of inches back of the herculeanus worker. Immediately the small worker changed its course and ran at full speed after the large one, catching up after traveling four or five inches, and at once attached itself to a hind tarsus. After watching this interesting battle for a considerable time the large worker was captured and placed in a cyanide bottle.

There are many other points to be mentioned in connection with this introduced pest, such as its probable future distribution, its natural enemies, measures of control, and the manner in which it is likely to affect various agricultural and commercial interests, were space to permit. The problem presented by this species is a large and complicated one and much tedious work of investigation will have to be done before the economic entomologist ean claim a victory over this small but formidable foe.

This paper was listened to with much interest by the members present. Mr. H. E. Weed stated that workers of this species will carry food to their nests for a distance of three quarters of a mile. He said that people who did not live in the infested district utterly failed to appreciate the havoc that these insects were causing.

Three closely related papers were next presented, as follows :

\section{LIFE HISTORY, HABITS AND METHODS OF STUDY OF OF THE IXODOIDEA.}

BY W. A. Hooker, Bureau of Entomology, U. S. Department of Agriculture.

The intention in presenting this paper upon the life history and

eDetermined by Prof. W. M. Wheeler. 


\section{$2 \mathrm{BHL}$ Biodiversity Heritage Library}

Newell, Wilmon. 1908. "Notes on the habits of the Argentine or "New Orleans" ant, Iridomyrmex humilis Mayr." Journal of economic entomology 1(1), 21-34. https://doi.org/10.1093/jee/1.1.21.

View This Item Online: https://www.biodiversitylibrary.org/item/37189

DOI: https://doi.org/10.1093/jee/1.1.21

Permalink: https://www.biodiversitylibrary.org/partpdf/325762

\section{Holding Institution}

New York Botanical Garden, LuEsther T. Mertz Library

\section{Sponsored by}

The LuEsther T Mertz Library, the New York Botanical Garden

\section{Copyright \& Reuse}

Copyright Status: NOT_IN_COPYRIGHT

This document was created from content at the Biodiversity Heritage Library, the world's largest open access digital library for biodiversity literature and archives. Visit BHL at https://www.biodiversitylibrary.org. 